\title{
Introduction
}

\section{Special Focus on Age Discrimination in Forced Migration Law, Policy, and Practice}

\author{
CHRISTINA CLARK-KAZAK ${ }^{1}$
}

\section{Abstract}

This special focus of Refuge highlights the widespread but under-researched occurrence of age discrimination in forced migration law, policy, and practice. Using a conceptual lens of social age, authors analyze the ways in which people in situations of forced migration are treated differently on the basis of chronological age, biological development, and family status. By framing this differential treatment as discrimination, this special focus approaches age as an equity issue. Such an approach differentiates the articles presented here from other recent scholarship on specific age groups, which is framed largely in terms of their vulnerabilities and needs. This special focus is intended to stimulate further research and activism on age discrimination in all its forms in varying contexts of forced migration.

\section{Résumé}

L'accent particulier accordé à ce sujet dans Refuge souligne l'incidence généralisée, bien qu'insuffisamment étudiée, de la discrimination fondée sur l'âge dans la législation, la politique et la pratique concernant la migration forcée. À l'aide de l'optique théorique de l'âge social, les auteurs abordent une analyse du traitement différencié accordée aux personnes en situation de migration forcée en fonction de leur âge chronologique, de leur développement biologique et de leur statut familial. En considérant ces différences dans le traitement par l'entremise du cadre de la discrimination, l'âge est conçu en tant qu'enjeu d'équité dans l'optique de cette approche particulière. Une telle approche dans les articles présentés ici se démarque des travaux et recherches récentes sur les groupes d'âge spécifiques qui se conceptualisent plutôt en fonction des vulnérabilités et besoins des sujets concernés. Cette approche particulière vise à inciter des recherches ultérieures ainsi que des activités politiques concernant la discrimination fondée sur l'âge dans toutes ses manifestations dans les divers contextes de la migration forcée.

\section{Conceptualizing Age Discrimination in Contexts of Forced Migration}

$\mathrm{M}$

ost migration law and policy-both domestic and international-use chronological age as the predominant definition of generational categories. For example, Article 1 of the UN Convention on the Rights of the Child defines a child as "every human being below the age of eighteen years unless under the law applicable to the child, majority is attained earlier."2 age-based categories are reproduced in migration laws and policies. For example, at a domestic level, Canada's Immigration and Refugee Protection Act (IRPA) for the most part uses chronological age definitions of children and older people. 3 While intended to provide a clear-cut way to justify inclusion in (and exclusion from) age categories, this predominant reliance on chronological age is problematic for many reasons. 
First, as Kimberly Seibel and Stephanie J. Silverman point out in their articles in this volume, people in situations of forced migration may not necessarily know their chronological birthdate and/or may not have documents to prove it. In the absence of "proof" of their chronological age, displaced people faced with entering demographic data on migration forms may be obliged to invent what Seibel calls "bureaucratic birthdates,"4 with far-reaching administrative consequences in access to services structured according to chronological age categories. Absence of proof for unaccompanied minors in the United Kingdom has also led to the use of controversial age assessments as an imposed "solution" to age disputes in order to legitimize the conception of "real" children, as Silverman explains.

Second, chronological age categories are arbitrary in the sense that they really only mark the passage of time. While in Western medical, psychological, and educational circles, there has been a tendency to assume that chronological age is a proxy for biological, cognitive, and social development, recent research in these fields indicates a wide range of variation on all these issues due to a combination of genetic and environmental factors. 5 Another indicator of the arbitrary nature of chronological age categories relates to the wide variation of definitions even within the same document. For example, in IRPA, while children are generally defined as under the age of eighteen, there are different chronological age requirements for application processes. ${ }^{6}$

Third, in many contexts, other biological and social markers of age are as, if not more, important than chronological age. These include puberty, marital status, parenthood and child rearing, formal employment, enrolment in education, and menopause. ${ }^{7}$ It should also be noted that some age categories-such as children-refer to a period of human development, as well as a social and familial relationship.

In response to these flaws within the prevailing chronological approach to age, authors in this volume have adopted the complementary concept of social age. Social age refers to "socially constructed meanings applied to physical development and roles attributed to infants, children, young people, adults and elders, as well as their intra- and intergenerational relationships." 8 Being attentive to these power relations, articles in this special focus analyze discrimination on the basis of chronological age, social age, and family status. By highlighting age discrimination, we are interested in politicizing age and recognizing it as an equity issue. This approach differentiates our scholarship from many studies in migration literature, which frames age primarily in terms of vulnerability and needs.

\section{Age as an Equity Issue: ${ }^{9}$ Defining Discrimination}

In this special focus, authors address direct and indirect, as well as positive and negative discrimination. According to Article 2(2) of the European Council Directive 2000/78/EC, direct discrimination occurs when "one person is treated less favourably than another has been or would be treated in a comparable situation." Here, the idea of equality centres on "the Aristotelean notion that likes should be treated alike." 10 Direct discrimination is evident in, for example, age-based criteria for migrants in "skilled worker" categories in Australia, Canada, and New Zealand. ${ }^{11}$ Indirect discrimination, in contrast, involves "instances of apparently equal treatment which impacts more heavily on people of a certain age."12 For example, fixed timeframes for residency requirements have differential impacts on people in different stages of their lives and are relatively more significant for younger than older people.

While scholarship, litigation, and advocacy against gender and racial discrimination in immigration are prevalent, age issues have received much less attention, both domestically and internationally. Fredman argues that one of the reasons that age is belatedly considered in equality discussions and legislation is that it "does not define a discrete group. We have all been young, and we will all, if we are fortunate, become old."13 This has led some to make the "fair innings" argument: age-based discrimination will affect all of us at some point in our lives and, therefore, there is no real inequality on the grounds of age. Indeed, some argue that equity considerations dictate that older people receive less access to employment ${ }^{14}$ and health care ${ }^{15}$ so as to ensure that younger age groups get their "fair share" and reduce intergenerational inequity.

However, the "fair innings" argument is problematic for a number of reasons. First, as Fredman argues, "two life-spans cannot be genuinely compared" because there are too many variables in each individual's life and because of evolving legislative and policy changes, which will affect some people in certain age categories while others were not affected at that stage of their life. ${ }^{16}$ These issues are particularly relevant for our discussion of migration, where migration status intersects with age categories and where people are subject to different national jurisdictions at different stages of life as they cross borders. Second, Fredman points out that "the same event might affect two people of different generations quite differently, even if it occurs to both at the same age."17

In a widely cited Canadian case of Gosselin v Quebec (Attorney General) one of the dissenting judges, Bastarche (4 SCR 429) argued, 
While age is a ground that is experienced by all people, it is not necessarily experienced in the same way by all people at all times. Large cohorts may use age to discriminate against smaller, more vulnerable cohorts. A change in economic, historical or political circumstances may mean that presumptions and stereotypes about a certain age group no longer hold true. Moreover, the fact remains that, while one's age is constantly changing, it is a personal characteristic that at any given moment one can do nothing to alter. Accordingly, age falls squarely within the concern of the equality provision that people not be penalized for characteristics they either cannot change or should not be asked to change.

However, it should be noted that this was a dissenting opinion, and many policymakers and judges continue to use variations of the "fair innings" argument to justify discriminatory practices on the bases of age.

A second argument that is sometimes advanced to justify differential treatment is that this is necessary to recognize the different capacities and/or situations of different age groups. Indeed, in some cases, this differential treatment is positive, according particular age groups specific provisions and protections on the basis of their evolving capacities or loss of adaptability. For example, in 2012, the UN Committee on the Rights of the Child recommended that states "expeditiously and completely cease the detention of children on the basis of their immigration status." Not all differential treatment on the grounds of age is inherently discriminatory or negative. However, in some cases, assumptions about difference are not empirically proven, nor applicable to the particular individual. As argued above, biological aging processes differ across individuals based on both genetic and environmental factors. Moreover, difference should not preclude equality of opportunity. Feminists have long argued that equality does not mean sameness. ${ }^{18}$ According to Fredman, the focus should be on "the facilitation of choice or autonomy, the protection of dignity and the enhancement of participative democracy or social inclusion," despite differential experiences. ${ }^{19}$

\section{Literature on Age Discrimination in Migration Law, Policy, and Practice}

There is only an emerging body of literature and case law on age discrimination generally, with even less on age discrimination in migration contexts. In Western liberal democracies, the impetus for much of the work on age discrimination came from a concern about discrimination against older people in the labour force. The Age Discrimination in Employment Act (ADEA) was passed in 1967 in the United States to outlaw discrimination on the grounds of age in employment against workers over the age of forty. The Irish Employment Equality Act of 1998 prohibits age discrimination in employment against workers aged eighteen to sixty-five. The EU adopted a non-binding Code of Practice on Age Diversity in Employment in 2000. All of these provisions set important precedents, but are limiting: they address employment exclusively and apply to specific chronological age groups.

International human rights conventions are based on the principles of equality and dignity for all human beings. As Article 1 of the Universal Declaration of Human Rights states, all human beings are "born free and equal in dignity and rights." Age as a ground for discrimination is found more broadly in some national constitutions. ${ }^{20}$ Where the provisions of the constitution extend to all people in that country-regardless of citizenship-this opens the door for advocacy on eliminating age discrimination against migrants.

However, very little attention has been paid to the pervasive and systematic age discrimination in migration law, policy, and practice. Some literature exists on the limits to rights of children born in countries of asylum/migration to non-citizens. Claire Breen ${ }^{21}$ analyzes age discrimination in relation to Irish-born children of asylum-seekers, while Jacqueline Bhabha ${ }^{22}$ has similarly exposed the "citizenship deficit" of American-born children of migrants without status and children globally who are "functionally stateless" as the result of the irregular immigration status of their parents. ${ }^{23}$ Thronson has also extensively analyzed the rights of migrant children in the United States and argues that immigration law lags behind other areas of law in the implementation of children's rights. ${ }^{24}$

Research in Australia ${ }^{25}$ and Canada ${ }^{26}$ has challenged discrimination against migration of older people, on ethical, family reunification, and economic grounds. Importantly from a policy perspective, both studies provide empirical evidence that refutes assumptions that older people will be economic "burdens" to host communities.

While there is thus a nascent interest in age discrimination in migration, the literature is patchy-limited to specific issues (e.g., citizenship status and employment) and countries (Ireland, Australia, Canada, and the United States). Articles in this special focus begin to partially address knowledge gaps by covering a wider range of issues and countries, but much more research is necessary, as discussed in the final section.

\section{Key Themes in This Special Focus}

The four articles in this special focus address different thematic areas in different contexts of forced migration, but they share some common themes that help to advance understanding of discrimination on the basis of chronological age, biological development, and family status. One such 
theme is intersectionality: "the interrelation of multiple, crosscutting institutionalised power relations." ${ }^{27}$ GrossmanThomson's article specifically addresses the intersection of gender and social age in contexts of patriarchy and paternalism in Nepal, which lead to discriminatory laws preventing the out-migration to Gulf States of females under the age of thirty. Her analysis indicates that social norms about age and migration are conditioned by perceptions of gender and religion. Similarly, Silverman argues that the intersection of age, gender, and nationality results in "triple discrimination against male Afghan 'imposter-children." These articles demonstrate that age groups-whether defined by chronology or social markers-are not homogenous categories. There is diversity within age-related experiences based on other characteristics, particularly gender, religion, race, class, and migrant status. These power relations intersect to create overlapping experiences of discrimination.

Another important finding across the articles in the special focus is related to family status. Both Kanics's and Silverman's articles draw attention to "accompanied" vs. "unaccompanied" children. While the latter are often assumed to be particularly vulnerable, Kanics demonstrates how children who migrate with their parents are routinely denied access to migration-related decisions, despite "best interests of the child" provisions within the Convention on the Rights of the Child and domestic legislation. Indeed, the relative privileging of unaccompanied minors within national and international legislation may lead to what Silverman has cynically described as the "imposter child syndrome."

All articles address, in different ways, how legal categories have real consequences in people's everyday lives. Seibel's research underscores the transformation of "bureaucratic birthdates"-invented for administrative purposes-into unquestioned biographical "facts," which determine people's access to social services and funding. Silverman demonstrates how young migrants without documentation navigate legal definitions of childhood.

The research presented in this special focus highlights the pervasiveness of age discrimination in migration contexts across the world and across the age spectrum. In some cases, age discrimination is in contravention of age-related provisions, such as the "best interests of the child," as demonstrated by Kanics. At other times, age discrimination is explicitly part of national legislation, as per GrossmanThomson's research in Nepal.

\section{Recommendations for Future Work on Age Discrimination and Migration}

The articles in this special focus thus make important contributions to the emerging literature on age discrimination and migration, but much more remains to be done. First, research should build on these and other studies to implement a more holistic understanding of age, beyond chronologically defined essentialized age categories. We need to be thinking of age across the life course, and developing tools and understandings of age that take into account individual and cross-cultural variations in experiences. Given the pervasiveness of chronological age categories as efficient administrative indicators, there is a practical imperative to develop alternatives.

This leads to a second recommendation: the need for both normative and utilitarian arguments and advocacy against age discrimination. At a normative level, one can argue that age discrimination is unjust. However, policy and legal change is more likely to occur when these social justice arguments are accompanied by more pragmatic discussions of why age-biased laws and policies do not work in practice. For this, we need more empirical evidence to test assumptions upon which age-based differentiations are made. The literature reviewed above and the articles in this special focus provide some important case studies, but larger-scale quantitative initiatives would help to complement the literature, which relies mostly on smaller scale case studies in particular places and/or about specific age groups or immigration categories.

Third, there is a need for deep interdisciplinary collaborations in research on age discrimination. Even within the small number of articles in this special focus, the disciplines of law, philosophy, anthropology, and political science are represented. We need more of this interdisciplinary dialogue, with increased collaboration across the social and natural sciences. In particular, psychologists and physicians have much clinical evidence to offer and should be invited into discussions with legal and social science scholars to better understand the pervasive and multi-faceted areas of age discrimination.

Finally, we need concerted, international efforts to advocate for more attention to age discrimination. Scholars would benefit from partnerships with interested groups from outside of academia, including child rights and age rights organizations. To effect change, we need a broadbased movement that challenges age-based stereotypes and assumptions, which are deeply entrenched in law and policy and normalized in everyday social interactions.

\section{Notes}

1 The author gratefully acknowledges the research assistance of Emily Leahy and Neena Sethi. The workshop on which this special focus is based was funded by a grant 
from the Social Sciences and Humanities Research Council of Canada.

2 United Nations Convention on the Rights of the Child, General Assembly Resolution 44/25, 20 November 1989, http://www.ohchr.org/en/professionalinterest/pages/crc .aspx.

3 Johanna Reynolds and Christina Clark-Kazak, "Restructuring Canadian Refugee and Settlement Policy to Reduce Age Discrimination? A Social Age Analysis of the Canadian Immigration and Refugee Protection Act (IRPA) and Its Regulations" (paper presented at the Canadian Association for Refugee and Forced Migration Studies Conference, 17 May 2012, Toronto).

4 Seibel, this volume; see also Faith Nibbs, Belonging: The Social Dynamics of Fitting In as Experienced by Hmong Refugees in Germany and Texas (Durham: Carolina Academic Press, 2014).

5 John Gimley Evans, "Age Discrimination: Implications of the Ageing Process," in Age as an Equality Issue, ed. Sandra Fredman and Sarah Spencer, 11-20 (Oxford: Hart Publishing, 2003).

6 Reynolds and Clark-Kazak, "Restructuring Canadian Refugee and Settlement Policy."

7 See, for example, Christina Clark-Kazak, Recounting Migration: Political Narratives of Congolese Young People in Uganda (Montreal and Kingston: McGill-Queen's University Press, 2011).

8 Christina Clark-Kazak, "Towards a Working Definition and Application of Social Age in International Development Studies," Journal of Development Studies 45, no. 8 (2009): 1-18.

9 As indicated in the referencing, this section draws extensively on the seminal work of Sandra Fredman and Sarah Spencer and their edited volume Age as an Equality Issue: Legal and Policy Perspectives (Oxford: Hart Publishing, 2003). However, while Fredman and Spencer frame age as an equality issue, I have chosen to use the term equity. Equality connotes treating everyone equally, while equity recognizes and accommodates differential experiences and ability.

10 Sandra Fredman, "The Age of Equality," in Fredman and Spencer, Age as an Equality Issue, 38.

11 Simon Biggs, Marthe Fredvang, and Irjaa Haapala, "Not in Australia: Migration, Work and Age Discrimination," Australasian Journal on Ageing 32, no. 2 (2013): 125-9.

12 Claire Breen, Age Discrimination and Children's Rights: Ensuring Equality and Acknowledging Difference (Leiden: Martinus Nijhoff Publishers, 2006), 21.
13 Fredman, "Age of Equality," 21.

14 Samule Issacharoff and Erica Worth Harris, "Is Age Discrimination Really Age Discrimination: The ADEA's Unnatural Solution," New York University Law Review 72, no. 4 (1997): 780.

15 Alan Williams, "Intergenerational Equity: An Exploration of the 'Fair Innings' argument," Health Economics 6, no. 2 (1997): 117-32; Dennis McKerlie, "Equality between Age-Groups," Philosophy and Public Affairs 21, no. 3 (1992): 275-95.

16 Fredman, "Age of Equality," 38.

17 Ibid.

18 Joan W. Scotty, "Deconstructing Equality-versus-Difference: Or, the Uses of Poststructuralist Theory for Feminism," in Feminist Theory Reader: Local and Global Perspectives, ed. C. McCann and S.-K. Kim (New York: Routledge, 2003), 389.

19 Fredman, "Age of Equality," 38.

20 Anne-Marie Mooney Cotter, Just a Number: An International Legal Analysis on Age Discrimination (Hampshire, UK: Ashgate, 2008).

21 Breen, Age Discrimination and Children's Rights.

22 Jacqueline Bhabha, "The Citizenship Deficit: On Being a Citizen Child," Development 46, no. 3 (2003): 53-9.

23 Jacqueline Bhabha, “Arendt's Children: Do Today's Migrant Children Have a Right to Have Rights?" Human Rights Quarterly 31 (2009): 410-51.

24 David B. Thronson, "Kids Will Be Kids? Reconsidering Conceptions of Children's Rights Underlying Immigration Law," Ohio State Law Journal 63 (2002): 979-1016; and David B. Thronson, "Entering the Mainstream: Making Children Matter in Immigration Law," Fordham Urban Law Journal 37 (2010): 393-413.

25 Biggs, Fredvang, and Haapala, "Not in Australia."

26 Madine VanderPlaat, Howard Ramos, and Yoko Yoshida, "A Preliminary Investigation of the Contributions of Sponsored Parents and Grandparents in Canada," Canadian Journal of Ethnic Studies 44, no. 3 (2012): 79-96.

27 Johanna Brenner, Women and the Politics of Class (New York: Monthly Review, 2000), 293.

Christina Clark-Kazak is associate professor, International Studies, at York University's bilingual Glendon campus. She may be contacted at cclark-kazak@glendon.yorku.ca 